\title{
How can we improve air pollution? Try increasing trust first
}

\author{
Bridget Lynn Hoffmann, ${ }^{1 \star}$ (D) Carlos Scartascini, ${ }^{1}$ and Fernando G. Cafferata ${ }^{2}$ \\ ${ }^{1}$ Inter-American Development Bank, Washington, DC, USA and ${ }^{2}$ National University of Tres de Febrero, \\ Buenos Aires, Argentia \\ ${ }^{\star}$ Corresponding author. E-mail: bridgeth@iadb.org
}

(Submitted 31 January 2021; revised 2 August 2021; accepted 9 September 2021; first published online 10 December 2021)

\begin{abstract}
Environmental policies are characterized by salient short-term costs and long-term benefits that are difficult to observe and to attribute to the government's efforts. These characteristics imply that citizens' support for environmental policies is highly dependent on their trust in the government's capability to implement solutions and commitment to investments in those policies. Using novel survey data from Mexico City, we show that trust in the government is positively correlated with citizens' willingness to support an additional tax approximately equal to a day's minimum wage to improve air quality and greater preference for government retention of revenues from fees collected from polluting firms. We find similar correlations using the perceived quality of public goods as a measure of government competence. These results provide evidence that mistrust can be an obstacle to better environmental outcomes.
\end{abstract}

Keywords: air pollution; trust; public services quality; taxes; public goods; publicly provided private goods; Mexico

JEL classification: Q53; Q52; Q56; H23; H41; H42

\section{Introduction}

Air pollution is one of the primary environmental and public health challenges facing governments. In 2013 alone, an estimated 5.5 million lives were lost due to exposure to outdoor and indoor air pollution and welfare losses reached more than US $\$ 5$ trillion worldwide (World Bank and Institute for Health Metrics and Evaluation, 2016). The problem is especially acute in low- and middle-income countries, where 90 per cent of the population is exposed to high levels of ambient air pollution (World Bank and Institute for Health Metrics and Evaluation, 2016). Given the substantial human and economic costs, why don't governments in the developing world implement more and stricter policies and regulations to reduce air pollution? 
Although citizens recognize that air pollution is a problem, they may not trust that the government has the capacity and the commitment to implement effective, longterm solutions (Scartascini and Tommasi, 2010, 2014; Franco Chuaire et al., 2017). ${ }^{1}$ The characteristics of many environmental public policies provide an opportunity for governments to act opportunistically. Many environmental policies are characterized by short-term costs and long-term commitments and the effectiveness of environmental policies are often difficult for citizens to observe since natural processes (e.g., thermal inversions) outside the government's control also effect outcomes. In low-trust environments, citizens may not be willing to support policies that require short-term costs and long-term commitments (Keefer et al., 2018, 2020). Therefore, one reason that governments in developing countries do not pursue and implement policies that lead to better air quality may be that they lack the trust to garner citizen support for effective policies.

We analyze the relationship between trust and demand for public policies related to air pollution using survey data from Mexico City (CDMX), where air quality has historically been a notorious problem. The United Nations described Mexico City's air as the most polluted on the planet in $1992 .^{2}$ Since then, CDMX's air pollution has improved, but it is still above international targets and ranked 30th worst among capital cities of the world (IQAir, 2018). Citizens are aware of the issue; in our survey data, nearly 95 per cent of participants report that air quality is "a problem" or "a very big problem" in Mexico City. ${ }^{3}$

Similar to many other low- and middle- income countries, Mexico's citizens have relatively low trust in the government, especially in politicians. According to an OECD survey of 42 countries, Mexico falls near the median in terms of trust in government. ${ }^{4}$ Citizens can proxy for opportunistic or untrustworthy behavior by the ability of governments to deliver on promises and whether politicians engage in corruption. Mexico ranks poorly on both metrics. Mexico's governance capabilities are below those of other OECD countries. ${ }^{5}$ According to the Transparency International Corruptions Perception Index available from the World Bank, Mexico ranked in the bottom 30 per cent of countries in 2018. ${ }^{6}$ According to the World Economic Forum Global Competitive Index available from the World Bank, in 2017 Mexico ranked 127th out of 137 countries in terms of beliefs in politicians' ethical standards. ${ }^{7}$ Despite this low ranking, Mexico is near the median for Latin America and the Caribbean. In terms of trust in government

\footnotetext{
${ }^{1}$ Similarly, corruption lowers willingness to pay for public goods and services.

${ }^{2}$ See https://www.c40.org/profiles/2013-mexicocity.

${ }^{3}$ The (translated) survey question is: "In general, do you think air pollution is a problem in Mexico City?" and the response categories are "No, it is not a problem," "It is a problem to some extent," "It is a problem," and "It is a very big problem."

${ }^{4}$ Trust in government refers to the share of people who report having confidence in the national government. See https://data.oecd.org/gga/trust-in-government.htm.

${ }^{5}$ For example, according to the Worldwide Governance Indicators, low- and middle-income countries, including Mexico, rank significantly below high-income OECD countries in terms of the governance indicators voice and accountability, political stability and absence of violence/terrorism, government effectiveness, regulatory quality, rule of law, and control of corruption. See https://info.worldbank.org/governance/wgi/ Home/Reports.

${ }^{6}$ See https://tcdata360.worldbank.org/indicators/h345264a2? country=MEX\&indicator=32534\&countri es=BRA\&viz $\backslash \backslash=$ choropleth\&years $=2018$.

${ }^{7}$ The survey question is: "In your country, how would you rate the ethical standards of politicians?" The response scale ranges from $1=$ extremely low to $7=$ extremely high. See https://tcdata360.worldbank.org/ indicators/h5f2277ca?country=MEX\&indicator=41322\&viz=line_chart\&years=2007.
} 
and corruption perceptions, Mexico City falls near national averages. Sixty per cent of citizens in Mexico City have no trust in government, compared to the national average of 54 per cent. ${ }^{8}$ Similarly, 90 per cent of citizens of Mexico City believe there is corruption in government, compared to 87 per cent of Mexicans nationally. ${ }^{9}$

In this context of high air pollution and low trust, we study whether trust affects citizens' willingness to pay taxes to improve air quality, views on whether pollution fees should be retained by the government or distributed to citizens, and preferences on whether the revenue should be used to fund the provision of environmental public or private goods. We use novel data collected from in-person household surveys between June and August 2019 and construct absolute and relative (benchmarking the trust scale to the individual's reported trust in their family) measures of trust.

Overall, we find that about 3 out of 4 participants would be willing to pay an additional tax in order to alleviate air pollution problems, and this willingness is higher for those who trust the President (by about 3 to 5 percentage points for a 1-unit increase on a 4point trust scale) and non-political actors such as NGOs. Participants have a preference for allocating the potential fees paid by polluting firms to citizens rather than the government. However, those who trust political figures, such as political parties or the Mayor of Mexico City, are more willing to let the government retain more of the revenue (by 2 to 5 percentage points for a 1 -unit increase on a 4 -point trust scale). Finally, we find that participants are more likely to report that they prefer allocating the revenue received by the government to providing public goods rather than providing private goods to individuals. Trust in government is not correlated with preferences for public goods, but trust in NGOs (positively) and neighbors (negatively) is.

In addition to absolute and relative measures of trust, we also look at correlations between policy preferences and perceptions of the quality of public services. Perceived quality of public services captures one dimension of trust in government (competence) that may suffer less measurement bias. We find that people's assessment of street quality in their neighborhood is correlated with higher willingness to pay an additional tax for an improvement in air quality and that higher quality of water service is correlated with a preference for greater government retention of revenue from fees collected from polluting firms. We do not find any significant correlation between perceived public goods quality and the use of the revenue for private or public goods.

Our results complement recent literature demonstrating that environmental policy preferences are influenced by trust in institutions, authorities and other citizens, such as family, friends and neighbors (Hammar and Jagers, 2006; Konisky et al., 2008; Jagers et al., 2010; Fairbrother, 2016; Kulin and Johansson Sevä, 2020). Specifically, trust is correlated with citizens' willingness to support taxes to curb pollution and climate change (Hammar and Jagers, 2006; Birol and Das, 2012; Harring, 2013; Harring and Jagers, 2013; Fairbrother, 2016; Xu and Li, 2016; Kulin and Johansson Sevä, 2020) and trust plays a role in determining the set of policies that individuals are willing to support (Zannakis et al., 2015; Harring, 2018; Lafuente et al., 2018). Similarly, government quality plays an important role in determining individuals' willingness to pay environmental taxes (Davidovic et al., 2020). ${ }^{10}$

\footnotetext{
${ }^{8}$ See the World Values Survey Wave 2017-2020 at https://www.worldvaluessurvey.org/WVSOnline.jsp.

${ }^{9}$ See the "Encuesta Nacional de Calidad e Impacto Gubernamental (ENCIG)" conducted in 2019 at https://www.mexicosocial.org/87-cree-que-hay-corrupcion-en-su-gobierno/.

${ }^{10}$ Trust and government corruption also play a role in willingness to pay for public goods and services more generally (Oh and Hong, 2012; Kassahun et al., 2020).
} 
Our study is most similar in spirit to Keefer et al. $(2018,2020)$, although they focus on the education and policing sectors. Education and policing differ from ambient air quality in that there are clear private alternatives to publicly provided goods. Therefore, Keefer et al. $(2018,2020)$ capture a preference for the size of government in those sectors by asking participants their preference on public or private provision. In contrast, our study captures willingness to pay an additional tax for an improvement in ambient air quality that could not be easily privately provided. Additionally, unlike Keefer et al. $(2018,2020)$, in which there is an implied or explicitly stated temporal misalignment of the costs and benefits, we study hypothetical short-term policies in which we specify that the costs and benefits of the policy (tax and a sufficient improvement in air quality to reduce the number of contingencias) occur in the same time period. ${ }^{11}$ This precludes confounding by time preferences. Further, in contrast to Keefer et al. (2018, 2020), our survey questions specify the amount of the tax increase and the benefits of the policy in terms of improvements in air quality to fix ideas.

Our results provide evidence that contributes to the literature on the role of trust in environmental public policy in several dimensions. First, we study willingness to pay an additional tax approximately equal to a day's minimum wage to achieve a specific improvement in the local air quality. In contrast, most of the literature has focused on a hypothetical tax, which may or may not be borne by the individual, to mitigate an environmental problem with uncertain local costs. Because the costs and benefits of the tax are concrete and salient, we can evaluate the roles of trust and public good provision on willingness to pay for environmental improvements with fewer confounding factors.

Second, we provide evidence in an understudied context and two understudied areas of the literature. We provide some of the first evidence on the role of trust in environmental policy preferences in Latin America where trust in government is low and air pollution is high. This context is distinct from the high-trust, low-pollution contexts in which most studies were conducted. ${ }^{12}$ We study a larger set of policy outcomes and additional measures of trust. In addition to studying willingness to pay an additional tax for environmental improvements, we also study preferences for government control of revenue for improving environmental quality and preferences on public vs. private environmental goods. In addition to reported levels of trust in government, we study the correlation between the perceived quality of public goods provision and environmental policy preferences. The perceived public service provision may provide a more objective measure of trust in government competence, which reduces measurement error.

Third, due to methodological improvements, our survey was particularly welldesigned for capturing policy preferences (Gingerich and Scartascini, 2018). We measured preferences for the distribution of revenue to the government or citizens and for spending on public goods or private goods using a procedure that replicated real-life

\footnotetext{
${ }^{11}$ Contingencias are environmental emergencies that are declared on days in which air pollution levels exceed or are predicted to exceed official Mexican standards and trigger measures such as restrictions on driving and industry, the suspension of some construction activities, and suspension of outdoor activities at day care facilities. See http://legismex.mty.itesm.mx/instruc/manual_contingencias.pdf and http://www. sadsma.cdmx.gob.mx:9000/datos/glosario-definicion/Contingencia\%20Ambiental.

${ }^{12}$ Most of the literature is from the United States (Konisky et al., 2008; Dincer and Fredriksson, 2018), Europe (Hammar and Jagers, 2006; Harring, 2014; Zannakis et al., 2015; Volland, 2017; Harring, 2018; Lafuente et al., 2018), and China (Sun et al., 2016; Zhong and Hwang, 2016; Gong et al., 2017; Dong and Zeng, 2018).
} 
budget trade-offs. Instead of asking about their priority, participants distributed hypothetical resources (10 units) among the several alternatives as a real-life representation of the choices being made across options.

\section{Hypotheses and Methodology}

Effective environmental public policy is crucial to sustainable and equitable economic growth. If trust in government plays a significant role in environmental public policy preferences, this is one additional channel through which trust may impact economic growth.

Trust is likely to play a particularly large role in environmental public policy, as these policies tend to require long-term investments and commitments on the part of the government and deliver benefits that are difficult for citizens to measure. For example, air quality depends on emissions, which can be influenced by policies and regulations, but also on weather and thermal inversions. Therefore, there are opportunities for politicians to act opportunistically. Furthermore, many environmental public policies deliver improvements in public goods, which citizens may not trust the government to provide. ${ }^{13}$ Using a probabilistic voting model, Keefer et al. (2020) show that voters prefer government spending with certain and immediate benefits when they have low trust in electoral promises and, in equilibrium, candidates promising larger allocations to transfers and short-term public goods are more likely to win elections in settings with low trust and high impatience.

We consider the role of trust in three key aspects of citizens' support for environmental public policy: willingness to pay taxes to finance new policies, preference for the share of revenue that the government controls, and the use of government revenue to finance public vs. private goods. Together, these three outcomes provide a fairly comprehensive view of citizens' support for environment public policies.

Trust may be difficult for citizens to quantify on a 4-point scale, but citizens are likely to have a clear evaluation of the quality of basic public goods that they use daily. Therefore, the perceived quality of public goods such as roads and piped water captures one dimension of trust in government, specifically competence, which may suffer less measurement bias.

Consequently, we focus on the following six specific hypotheses that correlate trust and environmental public policy.

1. Trust in government is positively correlated with support for taxes to improve air quality.

2. Trust in government is positively correlated with support for government retention of revenue from air pollution fees.

3. Trust in government is positively correlated with support for environmental public goods spending.

4. The perceived quality of local public goods and services is positively correlated with support for taxes to improve air quality.

5. The perceived quality of local public goods and services is positively correlated with support for government retention of revenue from air pollution fees.

\footnotetext{
${ }^{13}$ Trust as the basis of cooperation in the provision of public goods has a long tradition in the literature, including in environmental issues (Cardenas and Ostrom, 2004; Gächter et al., 2004; Bouma et al., 2008; Irwin et al., 2015).
} 
6. The perceived quality of local public goods and services is positively correlated with support for environmental public goods spending.

To evaluate if these hypotheses hold in our novel data from Mexico City, we estimate a linear OLS regression including Basic Geostatistical Area (i.e., neighborhood) fixed effects and basic socio-demographic characteristics and policy preferences/environmental beliefs as control variables with robust standard errors.

$$
Y_{i}=\beta_{0}+\beta_{1} T_{i}+\beta_{2} X_{i}+\beta_{3} E_{i}+\beta_{4} B G A_{i}+\epsilon_{i}
$$

where $Y i$ is the outcome of interest for individual $i$. We consider three outcomes of interest: an indicator variable representing support for a 100-peso pollution tax, how much of the revenue from air pollution fees should be retained by the government and distributed to citizens (measured as the share of resources retained by the government and as the difference in units allocated to government control and to citizen control), and how much of the revenue from air pollution fees should be dedicated to financing environmental public goods and environmental private goods (measured as the share of resources allocated to public goods spending and as the difference in units allocated to public goods and to private goods). $T$ contains trust variables (either absolute or relative) or perceived public services quality. $X$ is a set of socio-demographic control variables including gender, age, education, household size, and an indicator variable indicating the presence of children in the household. ${ }^{14} E$ contains additional variables representing perceptions of the government's environmental program capabilities and beliefs about the importance of environmental policies as control variables. Specifically, $E$ includes variables that capture perception of the effectiveness of CDMX's air pollution control program, perception of the government of CDMX's pollution control capacities, and the importance that politicians should place on environmental quality to receive the majority of votes. $B G A$ is a vector of fixed effects for the Basic Geostatistical Area to absorb the neighborhood-level quality of public services provision, political leaning and income.

In addition to results of regressions with individual trust variables, we show the results of regressions including the full set of trust variables to account for the omitted variable bias in the first specification since the trust variables are highly correlated. ${ }^{15}$

The first, second and third hypotheses imply that those who trust the government both in absolute and relative terms (the distance between trust in family and friends and trust in government) are more likely to support additional taxes to avoid air pollution environmental emergencies, prefer the government to retain more revenue from air pollution fees, and prefer to allocate more revenue to environmental public goods spending rather than environmental private goods spending.

Similarly, the fourth, fifth and sixth hypotheses imply that those who perceive the quality of local government public goods and services to be higher are more likely to support additional taxes to avoid air pollution environmental emergencies, prefer the government to retain more revenue from air pollution fees, and prefer to allocate more revenue to environmental public goods spending rather than environmental private goods spending.

\footnotetext{
${ }^{14}$ Household income is not used as control because it contains many missing observations.

${ }^{15}$ Table A1 in the online appendix shows that the set of trust variables are highly correlated.
} 


\section{Data}

The survey data used in this article were collected through in-person household surveys in Mexico City during the period June-August 2019 as part of a larger randomized controlled trial. The sample consists of 1,869 individuals. Sampling of households was restricted by education level and previous inclusion in other survey rounds and to ensure the safety of the field teams. Specifically, the sample included Basic Geostatistical Areas (BGAs) with an education level below the median and a homicide rate below the 70th percentile. $^{16}$

Field work proceeded as follows. Each day, each field team conducted surveys in one BGA. ${ }^{17}$ The day before surveying an area, households were given advance notice of the survey. In each sampled BGA, the field team distributed 500 invitations on both sides of the street starting at the northwestern most block of the selected BGA and moving toward the southeastern most block of the selected BGA until the 500-household quota had been reached. ${ }^{18}$ Surveyors followed the same pattern the following day when attempting to interview households.

Table 1 describes the observable characteristics of the sample used in the analysis. Thirty-five per cent of the sample is male, the average age is 42 years old, the average level of education is secondary education, 54 per cent of households have children, and on average households contain 4 members. Individuals in our sample believe that air pollution is a serious concern in Mexico City. Sixty-eight per cent of the individuals surveyed consider air pollution to be inevitable in any large city and 65 per cent consider air pollution to be inevitable in Mexico City. Twenty-nine per cent of the individuals surveyed think that Mexico City's government takes effective measures to control air pollution. On average, participants rated the effectiveness of the Megalopolis Program a 6 (on a scale where 1 is ineffective and 10 is fully effective), and the effectiveness of the control carried out to measure compliance by companies a 5 . Relative to other issues, participants do not think political candidates should put too much weight on environmental policy in order to win elections (average rating of 3 out of 10 ).

\subsection{Trust variables}

Table 1 also provides descriptive statistics of participants' trust in different groups and institutions. Trust was reported on a 4-point scale that ranged from no trust (a value of 1) to a lot of trust (a value of 4). On average, participants report the greatest trust in family and friends (mean of 3.38), followed by trust in neighbors (mean of 2.53), trust in non-governmental organizations (NGOs) (mean of 2.51), and trust in the media (mean of 2.28). On the other end of the trust spectrum are political parties and government authorities. Individuals reported slightly higher trust in the President (mean of 2.29) than in the Mayor of CDMX (mean of 2.18). Trust in the President and the Mayor likely depends on the political affiliation of the participant. ${ }^{19}$ Political parties have a mean trust level of 1.73 . Because the survey asked about political parties in general, as

\footnotetext{
${ }^{16}$ Additionally, any BGA that was deemed too dangerous for the field team to visit according to a majority of votes cast by the field manager and supervisors was removed from the sample.

${ }^{17}$ If the BGA had fewer than 500 households, it was surveyed on the same day as a nearby (partner) BGA.

${ }^{18}$ There is flexibility in the exact path through the BGA depending on where households are located and the geography of the street pattern in the BGA.

${ }^{19} \mathrm{We}$ include BGA fixed effects in our regression equation to control for political leanings at the neighborhood level.
} 
Table 1. Summary Statistics (full sample).

\begin{tabular}{|c|c|c|c|c|c|c|}
\hline Variable & Description & $\underset{(1)}{N}$ & $\begin{array}{l}\text { Mean } \\
(2)\end{array}$ & $\begin{array}{l}\text { S.D. } \\
(3)\end{array}$ & $\begin{array}{c}\operatorname{Min} \\
(4)\end{array}$ & $\begin{array}{c}\operatorname{Max} \\
(5)\end{array}$ \\
\hline Age & Continuous & 1866 & 42 & 15 & 18 & 88 \\
\hline Gender & Dummy (Male = 1) & 1869 & 0.35 & 0.48 & 0 & 1 \\
\hline Education & $\begin{array}{l}\text { Scale }(0=\text { No education, } \\
\quad 4=\text { Superior education) }\end{array}$ & 1869 & 2.32 & 0.95 & 0 & 4 \\
\hline Family with children & Dummy (Yes=1) & 1869 & 0.54 & 0.50 & 0 & 1 \\
\hline Household Size & Continuous & 1869 & 3.97 & 1.77 & 1 & 13 \\
\hline Megalopolis Program & $\begin{array}{c}\text { Scale ( } 1=\text { Not effective, } \\
10=\text { Very effective) }\end{array}$ & 1820 & 5.77 & 2.62 & 1 & 10 \\
\hline $\begin{array}{l}\text { Pollution control } \\
\text { (Megalopolis) }\end{array}$ & $\begin{array}{c}\text { Scale ( } 1=\text { Not effective, } \\
10=\text { Very effective) }\end{array}$ & 1799 & 4.87 & 2.57 & 1 & 10 \\
\hline $\begin{array}{l}\text { Environmental quality } \\
\text { (policy topic) }\end{array}$ & $\begin{array}{l}\text { Scale }(0=\text { Not important, } \\
\quad 10=\text { All the importance) }\end{array}$ & 1852 & 2.98 & 2.28 & 0 & 10 \\
\hline $\begin{array}{l}\text { Air pollution inevitable in } \\
\text { big cities }\end{array}$ & Dummy (1=Yes) & 1854 & 0.68 & 0.47 & 0 & 1 \\
\hline $\begin{array}{l}\text { Air pollution inevitable in } \\
\text { CDMX }\end{array}$ & Dummy (1=Yes) & 1838 & 0.65 & 0.48 & 0 & 1 \\
\hline $\begin{array}{l}\text { Air pollution is a problem } \\
\text { in Mexico City }\end{array}$ & $\begin{array}{l}\text { Scale ( } 1=\text { Not a problem, } \\
4=\text { A big problem) }\end{array}$ & 1867 & 3.71 & 0.60 & 1 & 4 \\
\hline Air quality in the colonia & $\begin{array}{l}\text { Scale ( } 1=\text { Lower than city, } \\
4=\text { Better than city) }\end{array}$ & 1854 & 2.38 & 0.77 & 1 & 4 \\
\hline $\begin{array}{l}\text { Pollution: CDMX take } \\
\text { effective measures }\end{array}$ & Dummy (1=Yes) & 1844 & 0.29 & 0.45 & 0 & 1 \\
\hline Trust: Family and friends & $\begin{array}{l}\text { Scale }(1=\text { No trust, } \\
4=\text { Trust a lot })\end{array}$ & 1863 & 3.38 & 0.88 & 1 & 4 \\
\hline Trust: Neighbours & $\begin{array}{l}\text { Scale }(1=\text { No trust, } \\
4=\text { Trust a lot })\end{array}$ & 1855 & 2.53 & 0.96 & 1 & 4 \\
\hline Trust: People in the street & $\begin{array}{l}\text { Scale }(1=\text { No trust, } \\
4=\text { Trust a lot })\end{array}$ & 1864 & 2.11 & 0.93 & 1 & 4 \\
\hline Trust: Political Party & $\begin{array}{l}\text { Scale ( } 1=\text { No trust, } \\
\quad 4=\text { Trust a lot })\end{array}$ & 1855 & 1.73 & 0.81 & 1 & 4 \\
\hline Trust: President & $\begin{array}{l}\text { Scale }(1=\text { No trust, } \\
\quad 4=\text { Trust a lot })\end{array}$ & 1853 & 2.29 & 1.08 & 1 & 4 \\
\hline Trust: Mayor CDMX & $\begin{array}{l}\text { Scale ( } 1=\text { No trust, } \\
\quad 4=\text { Trust a lot })\end{array}$ & 1849 & 2.18 & 1.01 & 1 & 4 \\
\hline Trust: Media & $\begin{array}{l}\text { Scale ( } 1=\text { No trust, } \\
4=\text { Trust a lot })\end{array}$ & 1855 & 2.28 & 0.93 & 1 & 4 \\
\hline Trust: NGOs & $\begin{array}{l}\text { Scale }(1=\text { No trust, } \\
4=\text { Trust a lot })\end{array}$ & 1841 & 2.51 & 0.94 & 1 & 4 \\
\hline Trust F/F-Neighbours & Distance & 1850 & 0.84 & 1.03 & -3 & 3 \\
\hline Trust F/F-People/Street & Distance & 1858 & 1.26 & 1.08 & -3 & 3 \\
\hline
\end{tabular}


Table 1. Continued

\begin{tabular}{|c|c|c|c|c|c|c|}
\hline Variable & Description & $\begin{array}{c}\mathrm{N} \\
(1)\end{array}$ & $\begin{array}{l}\text { Mean } \\
(2)\end{array}$ & $\begin{array}{l}\text { S.D. } \\
(3)\end{array}$ & $\begin{array}{l}\text { Min } \\
(4)\end{array}$ & $\begin{array}{c}\operatorname{Max} \\
(5)\end{array}$ \\
\hline Trust F/F-Pol.Parties & Distance & 1849 & 1.65 & 1.08 & -3 & 3 \\
\hline Trust F/F-President & Distance & 1847 & 1.09 & 1.27 & -3 & 3 \\
\hline Trust F/F-Mayor CDMX & Distance & 1843 & 1.20 & 1.24 & -3 & 3 \\
\hline Trust F/F-Media & Distance & 1849 & 1.10 & 1.20 & -3 & 3 \\
\hline Trust F/F-NGO's & Distance & 1836 & 0.87 & 1.15 & -3 & 3 \\
\hline Water service frequency & $\begin{array}{l}\text { Scale ( } 1=\text { Everyday } \\
\text { interruptions, } 5=\text { Never } \\
\text { interrupts) }\end{array}$ & 1841 & 3.39 & 1.55 & 1 & 5 \\
\hline Street quality & $\begin{array}{c}\text { Scale ( } 1=\text { Very Bad, } \\
4=\text { Very Good) }\end{array}$ & 1847 & 2.21 & 0.71 & 1 & 4 \\
\hline Increase Tax & Dummy(1=Pay tax $)$ & 1847 & 0.74 & 0.44 & 0 & 1 \\
\hline $\begin{array}{l}\text { Distribution of Resources: } \\
\text { Government }\end{array}$ & $\begin{array}{l}\text { Scale }(-10=\text { Resources to } \\
\text { citizens, } 10=\text { Resources } \\
\text { to government) }\end{array}$ & 1824 & -5.38 & 6.09 & -10 & 10 \\
\hline $\begin{array}{l}\text { Use of Resources: Public } \\
\text { goods }\end{array}$ & $\begin{array}{l}\text { Scale }(-10=\text { Resources to } \\
\text { privates, } 10=\text { resources } \\
\text { to public) }\end{array}$ & 1837 & 2.74 & 5.84 & -10 & 10 \\
\hline Coin share: Government & $\begin{array}{l}\text { Proportion }(0=\text { no coins, } \\
1=\text { all coins })\end{array}$ & 1824 & 0.23 & 0.30 & 0 & 1 \\
\hline Coin share: Public & $\begin{array}{l}\text { Proportion }(0=\text { no coins, } \\
1=\text { all coins })\end{array}$ & 1837 & 0.64 & 0.29 & 0 & 1 \\
\hline
\end{tabular}

opposed to a specific political party, this illustrates people's low levels of trust in political organizations.

In addition to the absolute measures of trust, we also construct relative trust measures using trust in family and friends as a benchmark. ${ }^{20}$ Reported levels of trust may differ across individuals not only because of differences in trust but also because of differences in perceptions of the reporting scale. The relative measures of trust are constructed as the difference between the trust level reported for family and friends and the trust level reported for that party. In this way, the relative measures of trust remove differences in the perception of the trust scale by benchmarking trust in each party to the individual's trust in their family and friends. For relative measures of trust, a lower value indicates higher trust because it indicates that the individual trusts that party almost as much as they trust their family and friends. Eighty-one per cent of participants reported that they have the (weakly) highest level of trust in family and friends.

The survey also included two questions to evaluate participants' perceptions of the quality of public goods and services, to proxy for the quality or competence of government. Water service frequency captures the number of interruptions an individual experiences. On average, participants reported that their water service is interrupted

\footnotetext{
${ }^{20}$ Responses to the battery of trust questions is highly correlated within individuals. See table A1 in the online appendix.
} 
at least once a week (on this scale 1 represents interruptions every day and 5 represents never experiencing interruptions to water service). Street quality in their colonia is viewed as "poor" on average (measured on a 4-point scale where 1 represents very poor quality and 4 very good quality). Online appendix 10 displays the relevant sections of the questionnaire.

\subsection{Dependent variables}

The survey collected data on environmental policy preferences using three different questions that follow the framework developed in Keefer et al. $(2018,2020) .{ }^{21}$ Table 1 displays summary statistics for the outcome variables and online appendix 10 displays the relevant sections of the questionnaire. ${ }^{22}$

Our first outcome variable is an indicator variable that captures whether a participant supports an increase in their taxes to improve air quality. Specifically, the survey asked whether the participant would support a 100-peso tax if the government were to commit to a plan that reduces air pollution enough to avoid all environmental emergencies. Seventy-four per cent agreed with the statement (figure A1 in the online appendix).

Our second outcome captures participants' preference for how revenue collected from fees paid by polluting firms should be distributed (online appendix figures A2 and A3). Participants reported their preference for the allocation of the revenue by distributing 10 units across four different options: the government of the city where the polluting factory is located (mean of 12 per cent), the national government (mean of 11 per cent), the citizens located near the polluting factory (mean of 42 per cent), or the citizens of the city where the factory is located (mean of 35 per cent). Using the responses to this question, we created two versions of the dependent variable "distribution of resources." The first adds the number of units allocated to the local and national governments and divides this sum by 10 . The range of this variable is 0 (all revenue distributed to citizens) to 1 (all revenue retained by the government) and can be interpreted as the percentage of the revenue that the participant prefers the government to control. The average share allocated to governments was 0.23 , or 23 per cent, demonstrating that participants prefer that citizens control a greater share of the revenue from pollution fees than local or national governments. The second is the absolute difference in units allocated to the government vs. citizens. The sum of the units distributed to citizens is subtracted from the sum of the units distributed to local and national governments. This variable ranges from - 10 to 10 . On this scale, a value of 10 indicates that a participant assigned all the revenue to government control, a value of 0 indicates that the participant allocated an equal number of units to government control and citizen control, and a value of - 10 indicates that a participant assigned all the revenue to citizen control. The average of this variable is -5.38 , which indicates that, on average, participants distributed 5.38 more units (out of 10 units) to citizen control than to government control. ${ }^{23}$

Our third outcome captures participants' preferences on public goods and private goods (online appendix figures A4 and A5). Participants were asked what share of the revenue should be spent on environmental public goods and environmental private

\footnotetext{
${ }^{21}$ The relevant sections of the questionnaire are displayed in online appendix 10.

${ }^{22}$ Data on missing values for the outcome variables is displayed in online appendix table A3.

${ }^{23}$ Online appendix figure $\mathrm{A} 2$ shows the full distribution of units allocated to citizens and to the government.
} 
goods if the local government were to retain the revenue from pollution fees. Participants reported their preference by distributing 10 units across four options: government implementation of new measures and restrictions on pollution sources (mean of 30 per cent), reduction of air pollution in public buildings, for example through air filters (mean of 17 per cent), provision of masks and filters to households (mean of 33 per cent), and subsidies to households for the purchase of energy-efficient appliances (mean of 19 per cent). Similar to the second outcome, we construct two versions of this outcome variable. The first captures the share of resources that the participant prefers to be used for public goods, and the second captures the absolute difference in units allocated to public vs private goods. The first variable ranges from 0 to 1 , with an average allocation of 64 per cent to public goods. The second ranges from - 10 to 10 with an average of 2.74 , indicating that on average participants allocated 2.74 more units to public environmental goods than to private environmental goods. ${ }^{24}$

\section{Results}

\subsection{Trust}

Table 2 shows that we find evidence in support of hypotheses 1 and 2 but do not find evidence in support of hypothesis 3. Panel A shows that higher trust in the President, the Mayor, and political parties is associated with higher willingness to support a tax increase to improve air quality (hypothesis 1). In particular, in the specification including the full set of trust variables, a one-level increase in trust in the President is associated with an increase in the likelihood of supporting the additional tax of 3 percentage points (column (4)). Consequently, the probability that an individual responds that she is willing to pay the tax is about 21 per cent higher if she answered that she trusts the President a lot than if she answered that she does not trust the President at all. These results are in line with others in the literature. Jagers et al. (2010) find that trust in politicians is linked to support for a carbon tax, Hammar and Jagers (2006) find a positive correlation between support for increases in gasoline taxes and trust, and Harring and Jagers (2013) find that political trust and interpersonal trust have significant effects on people's attitudes toward an increase in taxes on carbon dioxide. A similar relationship is found between trust in NGOs and support for an additional tax to improve air quality. One reason may be that those who trust NGOs believe that NGOs play a role in ensuring government accountability.

Panel B of table 2 shows that higher trust in the President, the Mayor and political parties is also correlated with a greater preference for government (national and local) retention of the revenue from fees paid by polluting firms (hypothesis 2). In particular, in the specification including the full set of trust variables a one-level increase in trust in political parties and the Mayor results in a 5 percentage point and a 2 percentage point increase in the share of the revenue that a participant prefers the government to retain (column (4)). This implies that an individual who trust political parties a lot is willing to provide an approximately 110 per cent greater share of resources to government control than an individual who does not trust them at all. The same results can be seen in

\footnotetext{
${ }^{24}$ Online appendix figure A4 shows the full distribution of reported preference for environmental public or private goods spending
} 


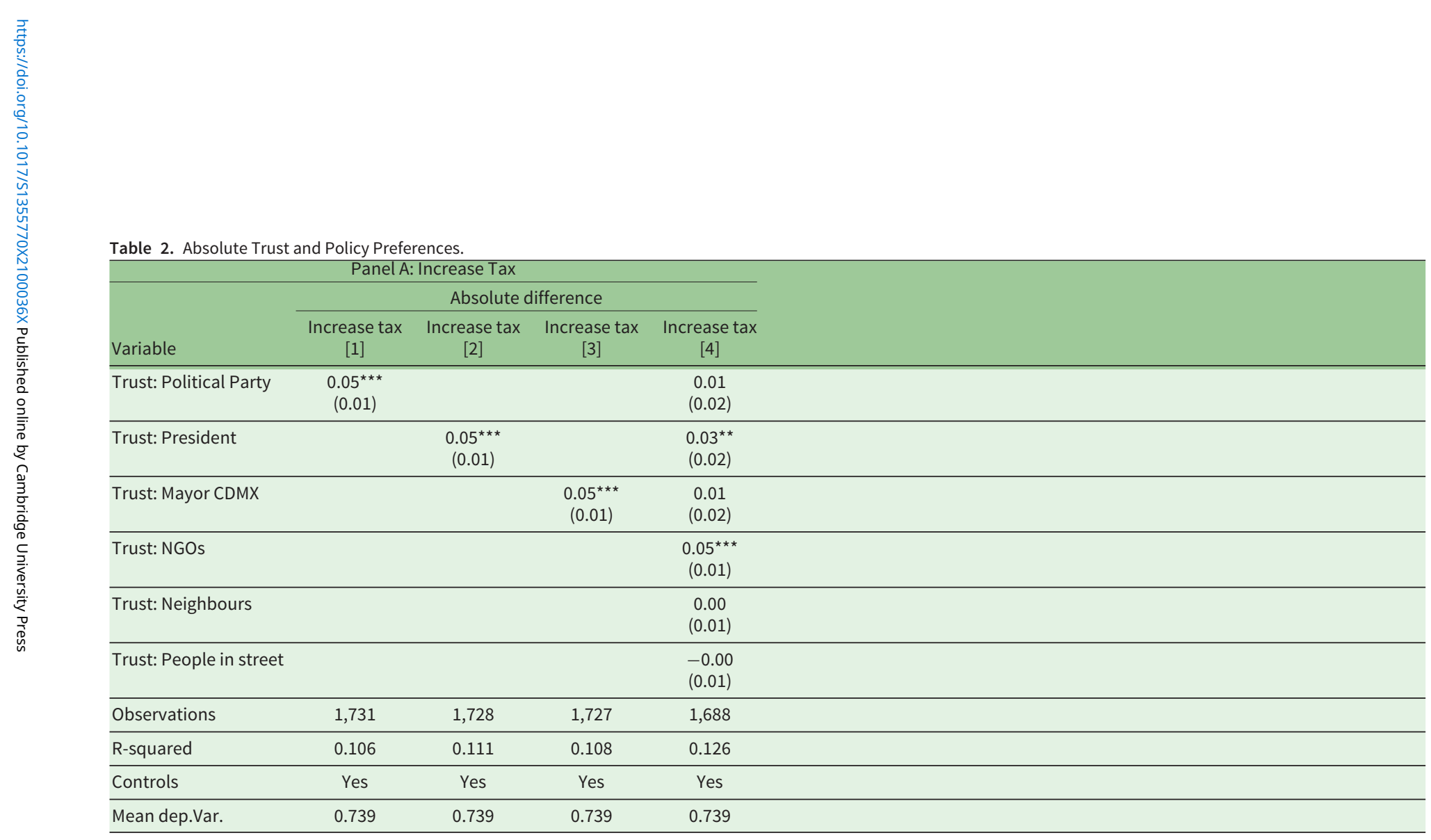




\begin{tabular}{|c|c|c|c|c|c|c|c|c|}
\hline \multicolumn{9}{|c|}{ Panel B: Distribution of Resources to Government } \\
\hline \multirow[b]{2}{*}{ Variable } & \multicolumn{4}{|c|}{ Share of units } & \multicolumn{4}{|c|}{ Absolute difference } \\
\hline & $\begin{array}{c}\text { Dist. of Res. } \\
\text { Gov. } \\
{[1]}\end{array}$ & $\begin{array}{c}\text { Dist. of Res. } \\
\text { Gov. } \\
\text { [2] }\end{array}$ & $\begin{array}{c}\text { Dist. of Res. } \\
\text { Gov. } \\
\text { [3] }\end{array}$ & $\begin{array}{c}\text { Dist. of Res. } \\
\text { Gov. } \\
{[4]}\end{array}$ & $\begin{array}{c}\text { Dist. of Res. } \\
\text { Gov. } \\
\text { [5] }\end{array}$ & $\begin{array}{c}\text { Dist. of Res. } \\
\text { Gov. } \\
{[6]}\end{array}$ & $\begin{array}{c}\text { Dist. of Res. } \\
\text { Gov. } \\
\text { [7] }\end{array}$ & $\begin{array}{c}\text { Dist. of Res } \\
\text { Gov. } \\
\text { [8] }\end{array}$ \\
\hline Trust: Political Party & $\begin{array}{c}0.06^{\star \star \star} \\
(0.01)\end{array}$ & & & $\begin{array}{c}0.05^{\star \star \star} \\
(0.01)\end{array}$ & $\begin{array}{c}1.20^{\star \star \star} \\
(0.20)\end{array}$ & & & $\begin{array}{c}1.02^{\star \star \star} \\
(0.23)\end{array}$ \\
\hline Trust: President & & $\begin{array}{c}0.03^{\star \star \star} \\
(0.01)\end{array}$ & & $\begin{array}{c}0.00 \\
(0.01)\end{array}$ & & $\begin{array}{c}0.66^{\star \star \star} \\
(0.15)\end{array}$ & & $\begin{array}{c}0.03 \\
(0.21)\end{array}$ \\
\hline Trust: Mayor CDMX & & & $\begin{array}{c}0.04^{\star \star \star} \\
(0.01)\end{array}$ & $\begin{array}{l}0.02^{*} \\
(0.01)\end{array}$ & & & $\begin{array}{c}0.78^{\star \star \star} \\
(0.16)\end{array}$ & $\begin{array}{l}0.42^{\star} \\
(0.22)\end{array}$ \\
\hline Trust: NGOs & & & & $\begin{array}{l}-0.01 \\
(0.01)\end{array}$ & & & & $\begin{array}{l}-0.27 \\
(0.17)\end{array}$ \\
\hline Trust: Neighbours & & & & $\begin{array}{c}0.01 \\
(0.01)\end{array}$ & & & & $\begin{array}{c}0.11 \\
(0.19)\end{array}$ \\
\hline Trust: People in street & & & & $\begin{array}{l}-0.00 \\
(0.01)\end{array}$ & & & & $\begin{array}{l}-0.05 \\
(0.19)\end{array}$ \\
\hline Observations & 1,715 & 1,714 & 1,713 & 1,675 & 1,715 & 1,714 & 1,713 & 1,675 \\
\hline R-squared & 0.137 & 0.124 & 0.127 & 0.144 & 0.137 & 0.124 & 0.127 & 0.144 \\
\hline Controls & Yes & Yes & Yes & Yes & Yes & Yes & Yes & Yes \\
\hline Mean dep.Var. & 0.231 & 0.231 & 0.231 & 0.231 & -5.385 & -5.385 & -5.385 & -5.385 \\
\hline
\end{tabular}




\begin{tabular}{|c|c|c|c|c|c|c|c|c|}
\hline \multicolumn{9}{|c|}{ Panel C: Use of Resources } \\
\hline \multirow[b]{2}{*}{ Variable } & \multicolumn{4}{|c|}{ Share of units } & \multicolumn{4}{|c|}{ Absolute difference } \\
\hline & $\begin{array}{c}\text { Use of Res. } \\
\text { Public goods } \\
\text { [1] }\end{array}$ & $\begin{array}{l}\text { Use of Res. } \\
\text { Public goods } \\
\text { [2] }\end{array}$ & $\begin{array}{c}\text { Use of Res. } \\
\text { Public goods } \\
\text { [3] }\end{array}$ & $\begin{array}{c}\text { Use of Res. } \\
\text { Public goods } \\
\text { [4] }\end{array}$ & $\begin{array}{l}\text { Use of Res. } \\
\text { Public goods } \\
\text { [5] }\end{array}$ & $\begin{array}{l}\text { Use of Res. } \\
\text { Public goods } \\
\text { [6] }\end{array}$ & $\begin{array}{l}\text { Use of Res. } \\
\text { Public goods } \\
\text { [7] }\end{array}$ & $\begin{array}{c}\text { Use of Res. } \\
\text { Public goods } \\
\text { [8] }\end{array}$ \\
\hline Trust: Political Party & $\begin{array}{c}0.01 \\
(0.01)\end{array}$ & & & $\begin{array}{c}0.00 \\
(0.01)\end{array}$ & $\begin{array}{c}0.16 \\
(0.20)\end{array}$ & & & $\begin{array}{c}0.04 \\
(0.24)\end{array}$ \\
\hline Trust: President & & $\begin{array}{c}0.01 \\
(0.01)\end{array}$ & & $\begin{array}{c}0.01 \\
(0.01)\end{array}$ & & $\begin{array}{c}0.19 \\
(0.15)\end{array}$ & & $\begin{array}{c}0.26 \\
(0.23)\end{array}$ \\
\hline Trust: Mayor CDMX & & & $\begin{array}{c}0.00 \\
(0.01)\end{array}$ & $\begin{array}{l}-0.01 \\
(0.01)\end{array}$ & & & $\begin{array}{c}0.06 \\
(0.15)\end{array}$ & $\begin{array}{l}-0.18 \\
(0.23)\end{array}$ \\
\hline Trust: NGOs & & & & $\begin{array}{l}0.02^{\star \star} \\
(0.01)\end{array}$ & & & & $\begin{array}{l}0.41^{\star \star} \\
(0.17)\end{array}$ \\
\hline Trust: Neighbours & & & & $\begin{array}{c}-0.02^{*} \\
(0.01) \\
\end{array}$ & & & & $\begin{array}{c}-0.31^{*} \\
(0.18) \\
\end{array}$ \\
\hline Trust: People in street & & & & $\begin{array}{l}-0.00 \\
(0.01)\end{array}$ & & & & $\begin{array}{l}-0.02 \\
(0.19)\end{array}$ \\
\hline Observations & 1,729 & 1,725 & 1,726 & 1,687 & 1729 & 1725 & 1726 & 1687 \\
\hline R-squared & 0.088 & 0.088 & 0.088 & 0.097 & 0.088 & 0.088 & 0.088 & 0.097 \\
\hline Controls & Yes & Yes & Yes & Yes & Yes & Yes & Yes & Yes \\
\hline Mean dep.Var. & 0.637 & 0.637 & 0.637 & 0.637 & 2.741 & 2.741 & 2.741 & 2.741 \\
\hline
\end{tabular}

Notes: Each panel shows regression results for a different dependent variable.

Each column shows the regression coefficient and robust standard error in parenthesis corresponding to an OLS regression.

${ }^{* * *} p<0.01,{ }^{* *} p<0.05,{ }^{*} p<0.1$

Demographic controls: age, gender, education, children dummy, number of household members, and BGA F.E.

Policy controls: Megalopolis program, Pollution control (Megalopolis) and Environmental quality (policy topic)

Trust control: Family and friends

Trust is measured in absolute terms (increasing levels trust with higher numbers) 
columns (5)-(8), which show the results using the absolute difference in the number of units assigned to government and citizen control as the outcome variable.

Panel C of table 2 shows that we do not find a statistically significant relationship between trust in the government and the preferred use of revenue from pollution fees to finance environmental public goods spending or environmental private goods spending (hypothesis 3). Part of the reason for this null result may be that the survey question asked individuals about the use of the revenue by the local government, and most participants were not willing to allocate a substantial share of the revenue to the local government (mean of 11 per cent in online appendix figure A3). However, we do find a correlation between the preferred use of revenue and trust in NGOs and in neighbors.

\subsection{Perceived Public Goods Quality}

Consistent with our results using trust variables, Table 3 shows that we find evidence consistent with hypotheses 4 and 5, but do not find evidence consistent with hypothesis 6. Panel A shows that perceived street quality is associated with a higher likelihood of supporting a specific tax to avoid air pollution contingencies (hypothesis 4). This finding complements similar results in the literature. For example, Xu and Li (2016) and Davidovic et al. (2020) find that quality of government plays an important role in an individual's willingness to pay for environmental taxes.

Panel B of table 3 shows that higher levels of reliability of water service provision (fewer interruptions in water service) are positively associated with support for government retention of revenue from air pollution fines (hypothesis 5). This finding complements evidence in the literature that associates government capacity with a preference for government spending on environmental issues (Kulin and Johansson Sevä, 2019).

Panel C of table 3 shows that we do not find a significant relationship between trust in government and the preference for spending on environmental public goods or environmental private goods (hypothesis 6).

\subsection{Robustness}

We show the robustness of our main results in four ways. First, we replicate table 2 using relative measures of trust. Relative measures of trust remove differences in participants' perceptions of the trust scale used to record their trust levels. Given the construction of the two sets of trust variables, we expect the coefficients in online appendix table A4 to be the opposite sign of those in table 2. Table A4 shows that the correlations between trust and policy preferences are robust to using relative trust measures.

Second, we show that our main results are robust to restricting the sample to participants who reported their highest level of trust in friends and family. This excludes 19 per cent of our sample, whose highest reported trust level is for a party other than friends and family. Since we assume that most individuals have the most trust in their friends and family, it is possible that participants who do not report their highest trust level for friends and family misunderstood the exercise. Online appendix table A5 shows that summary statistics for this sample are very similar to those of the full sample presented in table 1. Online appendix tables A7 and A8 show that the results using absolute trust and relative trust are consistent with the results for the full sample presented in table 2. 
Table 3. Public Service Quality and Policy Preferences

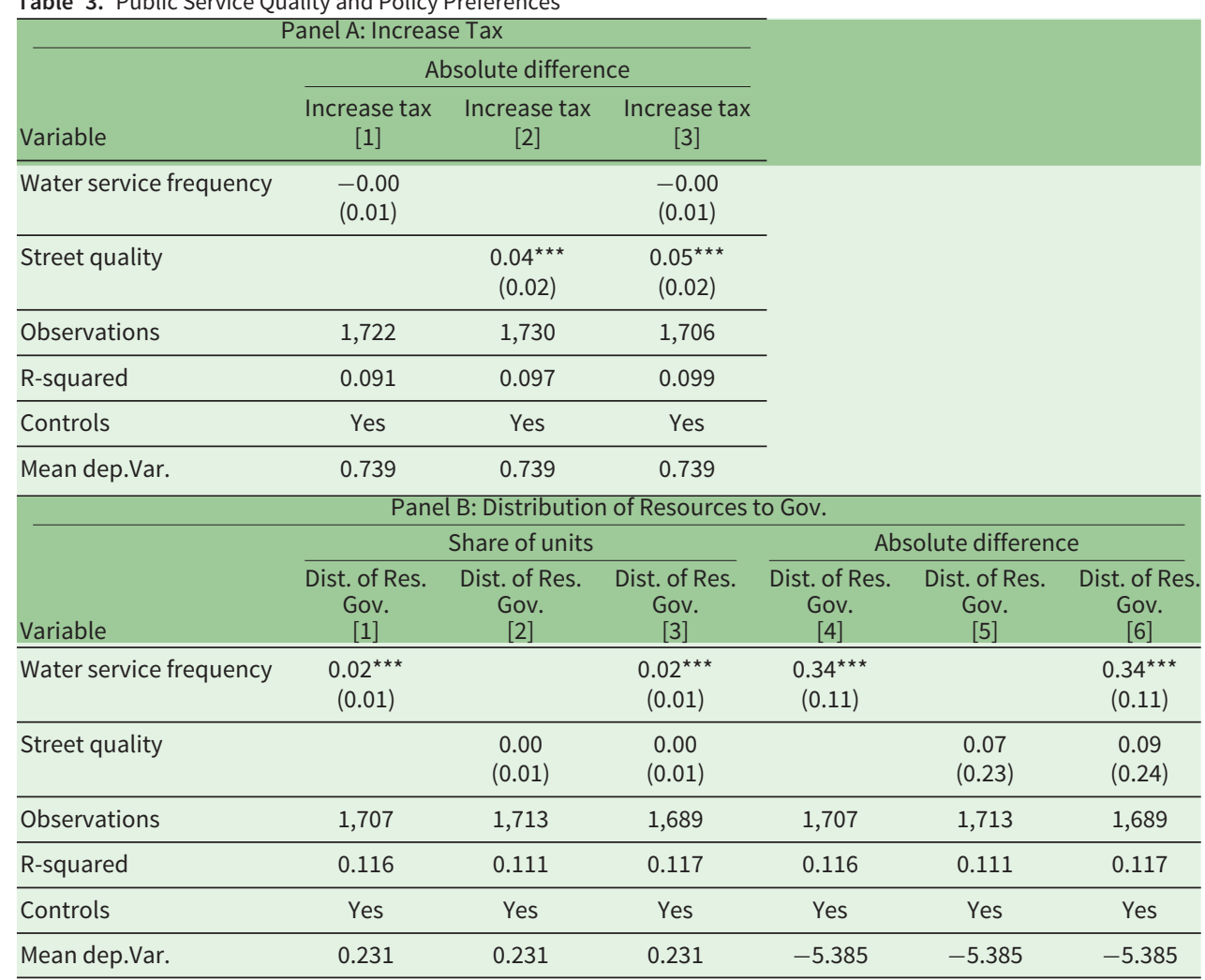




\begin{tabular}{|c|c|c|c|c|c|c|}
\hline \multicolumn{7}{|c|}{ Panel C: Use of Resources to Public Goods } \\
\hline \multirow[b]{2}{*}{ Variable } & \multicolumn{3}{|c|}{ Share of units } & \multicolumn{3}{|c|}{ Absolute difference } \\
\hline & $\begin{array}{l}\text { Use of Res. } \\
\text { Public goods } \\
\text { [1] }\end{array}$ & $\begin{array}{l}\text { Use of Res. } \\
\text { Public goods } \\
\text { [2] }\end{array}$ & $\begin{array}{c}\text { Use of Res. } \\
\text { Public goods } \\
\text { [3] }\end{array}$ & $\begin{array}{c}\text { Use of Res. } \\
\text { Public goods } \\
\text { [4] }\end{array}$ & $\begin{array}{l}\text { Use of Res. } \\
\text { Public goods } \\
\text { [5] }\end{array}$ & $\begin{array}{c}\text { Use of Res. } \\
\text { Public goods } \\
\text { [6] }\end{array}$ \\
\hline Water service frequency & $\begin{array}{c}0.00 \\
(0.01)\end{array}$ & & $\begin{array}{l}-0.00 \\
(0.01)\end{array}$ & $\begin{array}{c}0.02 \\
(0.12)\end{array}$ & & $\begin{array}{l}-0.02 \\
(0.11)\end{array}$ \\
\hline Street quality & & $\begin{array}{c}0.01 \\
(0.01)\end{array}$ & $\begin{array}{c}0.01 \\
(0.01)\end{array}$ & & $\begin{array}{c}0.23 \\
(0.22)\end{array}$ & $\begin{array}{c}0.23 \\
(0.23)\end{array}$ \\
\hline Observations & 1,719 & 1,724 & 1,700 & 1,719 & 1,724 & 1,700 \\
\hline R-squared & 0.085 & 0.089 & 0.088 & 0.085 & 0.089 & 0.088 \\
\hline Controls & Yes & Yes & Yes & Yes & Yes & Yes \\
\hline Mean dep.Var. & 0.637 & 0.637 & 0.637 & 2.741 & 2.741 & 2.741 \\
\hline
\end{tabular}

Notes: Each panel shows regression results for a different dependent variable.

Each column shows the regression coefficient and robust standard error in parenthesis corresponding to an OLS regression.

${ }^{\star \star \star} p<0.01,{ }^{\star \star} p<0.05,{ }^{\star} p<0.1$

Demographic controls: age, gender, education, children dummy, number of household members, and BGA F.E.

Policy controls: Megalopolis program, Pollution control (Megalopolis) and Environmental quality (policy topic)

Water service frequency: 1 (every day interruptions) to 5 (Never)

Street quality: 1 (Very bad) to 4 (Very good) 
Online appendix table A9 shows that the correlations between the perceived quality of public goods and policy preferences presented in table 3 are robust to using the trimmed sample.

Third, we show that our main results are robust to the inclusion of household income as an additional control. We do not include income as a control in our main specification because nearly half of our participants declined to report their household income. However, income could be correlated with reported trust levels, causing omitted variable bias. In the sample of participants who report their household income, online appendix tables A10 and A11 demonstrate that our main results are robust to including household income as an additional control.

Fourth, we use alternative estimation strategies. Our first outcome of interest, willingness to pay an additional tax, is binary so we show the robustness of our results to estimating a probit model. Our second and third outcome variables represent the share of revenue retained by the government and the share of revenue that participants prefers to finance public goods, are proportional, ranging from 0 to 1 , so we show the robustness of our main results to estimating a fractional logit model. Online appendix tables A12 and A13 show that our results are largely unchanged.

\section{Conclusion}

Trust levels in the Latin American region are lower than in other regions of the world and have been falling for the last two decades (Scartascini and Valle Luna, 2020a). This development holds significant implications, as trust facilitates transactions between individuals, firms and governments, and it also affects the relationship between citizens and the state (Keefer et al., 2018). If citizens have low trust in government, they will not be willing to support public policies that have intertemporally unbalanced costs and benefits, require high levels of competence to implement, have an effectiveness that is difficult to observe, and give governments greater discretion over how to allocate resources. Unfortunately, these characteristics are common to many public policies to improve air quality, and environmental public policies in general.

Using a novel database from a survey of about 2,000 citizens of Mexico City, we find correlational evidence supporting several of the hypotheses considered in this paper. Higher trust in government is correlated with higher reported willingness to pay an additional tax to reduce air pollution and with higher reported support for government retention of the additional revenue it collects from polluting firms. We do not find that higher trust in government is correlated with greater reported support for the provision of environmental public goods rather than environmental private goods by the local government. Relatively low preference for local government retention of the revenue may obscure preferences on public and private goods. We find similar results when using participants' evaluations of public good provision (street quality or water service frequency) as a measure of government competence. Those who receive (or perceive) better services tend to report greater support for an additional tax to improve air quality and more support for government control of revenue collected from polluting firms. Again, using perceived public goods quality as a measure of government competence, we find no relationship between trust in government and the reported preference for spending on environmental public or private goods.

While we provide new, specific evidence to the literature, there is still plenty to improve upon. For example, more granular measures of trust that separate competence 
from benevolence and honesty from predictability would provide more precise information about the dimensions of trust that matter most for environmental policy support. More importantly, causal evidence on the linkages between trust and policy demand, obtained, for instance, by allocating information about government qualities randomly across groups, would be a substantial improvement.

Although the results are based on correlations from a survey of about 2,000 individuals in Mexico City, they provide further evidence that trust in governments and institutions plays an important role in citizens' support for environmental and air quality policies. Fortunately, many steps that governments can take to increase their citizens' trust are simply good policies. For example, providing high quality public services and local investment (Scartascini and Valle Luna, 2020b; Carrillo et al., 2021), implementing effective responses to crises and disasters (Frost et al., 2020), and increasing the transparency of their actions (Alessandro et al., 2021) all provide direct benefits to citizens, while also leading to greater trust by citizens. In the long run, there is a virtuous circle connecting policies that generate greater trust with demand for better policies. Understanding the role of trust in the demand for air quality and climate change policies is particularly important since these are some of the largest collective actions problems of our generation.

Competing interests. The authors declare none.

Supplementary material. The supplementary material for this article can be found at https://doi.org/10. 1017/S1355770X2100036X.

Acknowledgements. This project received IRB approval from Harvard University Committee on the Use of Human Subjects as Protocol: IRB17-0091. The data collection was funded by a grant from the InterAmerican Development Bank. We are grateful to Sara Restrepo Tamayo for excellent research assistance and to IPA Mexico, especially Cosma Gabaglio, for coordinating and implementing field work.

\section{References}

Alessandro M, Cardinale LB, Scartascini C, Streb J and Torrealday J (2021) Transparency and trust in government. Evidence from a survey experiment. World Development 138.

Birol E and Das S (2012) Valuing the environment in developing countries: modeling the impact of distrust in public authorities' ability to deliver on the citizen's willingness to pay for improved environmental quality. Madras School of Economics Working Paper 55/2010.

Bouma J, Bulte E and Soest D (2008) Trust and cooperation: social capital and community resource management. Journal of Environmental Economics and Management 56, 155-166.

Cardenas JC and Ostrom E (2004) What do people bring into the game? Experiments in the field about cooperation in the commons. Agricultural Systems 82, 307-326.

Carrillo PE, Castro E and Scartascini C (2021) Public good provision and property tax compliance: evidence from a natural experiment. Journal of Public Economics 198, 104422.

Davidovic D, Harring N and Jagers SC (2020) The contingent effects of environmental concern and ideology: institutional context and people's willingness to pay environmental taxes. Environmental Politics 29, 674-696.

Dincer OC and Fredriksson PG (2018) Corruption and environmental regulatory policy in the United States: does trust matter?. Resource and Energy Economics 54, 212-225.

Dong K and Zeng X (2018) Public willingness to pay for urban smog mitigation and its determinants: a case study of Beijing, China. Atmospheric Environment 173, 355-363.

Fairbrother M (2016) Trust and public support for environmental protection in diverse national contexts. Sociological Science 3, 359-382. 
Franco Chuaire M, Scartascini C and Tommasi M (2017) State capacity and the quality of policies. Revisiting the relationship between openness and the size of the government. Economics and Politics 29, $133-156$.

Frost M, Kim S, Scartascini C, Zamora P and Zechmeister EJ (2020) Disaster and political trust: a natural experiment from the 2017 Mexico City earthquake. Unpublished manuscript.

Gächter S, Hermann B and Thönia C (2004) Trust, voluntary cooperation, and socio-economic background: survey and experimental evidence. Journal of Economic Behavior \& Organization 55, 505-531.

Gingerich D and Scartascini C (2018) A heavy hand or a helping hand? Information provision and citizen preferences for anti-crime policies. Technical report, Inter-American Development Bank.

Gong X, Yang S and Zhang M (2017) Not only health: environmental pollution disasters and political trust. Sustainability $\mathbf{9}, 575$.

Hammar H and Jagers SC (2006) Can trust in politicians explain individuals' support for climate policy? The case of CO2 tax. Climate Policy 5, 613-625.

Harring N (2013) Understanding the effects of corruption and political trust on willingness to make economic sacrifices for environmental protection in a cross-national perspective. Social Science Quarterly 94, 660-671.

Harring N (2014) Corruption, inequalities and the perceived effectiveness of economic pro-environmental policy instruments: A European cross-national study. Environmental Science \& Policy 39, 119-128.

Harring N (2018) Trust and state intervention: results from a Swedish survey on environmental policy support. Environmental Science \& Policy 82, 1-8.

Harring N and Jagers SC (2013) Should we trust in values? Explaining public support for proenvironmental taxes. Sustainability 5, 210-227.

IQAir (2018). 2018 world air quality report. Technical report, IQAir. Available at https://www.iqair.com/ world-most-polluted-cities/world-air-quality-report-2018-en.pdf.

Irwin K, Edwards K and Tamburello JA (2015) Gender, trust and cooperation in environmental social dilemmas. Social Science Research 50, 155-166.

Jagers SC, Löfgren Å and Stripple J (2010) Attitudes to personal carbon allowances: political trust, fairness and ideology. Climate Policy 10, 410-431.

Kassahun HT, Jacobsen JB and Nicholson CF (2020) Revisiting money and labor for valuing environmental goods and services in developing countries. Ecological Economics 177, 106771.

Keefer P, Scartascini C and Vlaicu R (2018) Shortchanging the future: the short-term bias of politics. In Izquierdo A, Pessino C and Vuletin G (eds.). Better Spending for Better Lives. How Latin America and the Caribbean Can Do More with Less. Development in the Americas report. Washington, DC, United States: Inter-American Development Bank.

Keefer P, Scartascini C and Vlaicu R (2020) Voter preferences, electoral promises, and the composition of public spending. Technical report, Inter-American Development Bank.

Konisky DM, Milyo J and Richardson LE (2008) Environmental policy attitudes: issues, geographical scale, and political trust. Social Science Quarterly 89, 1066-1085.

Kulin J and Johansson Sevä I (2019) The role of government in protecting the environment: quality of government and the translation of normative views about government responsibility into spending preferences. International Journal of Sociology 49, 110-129.

Kulin J and Johansson Sevä I (2020) Who do you trust? How trust in partial and impartial government institutions influences climate policy attitudes. Climate Policy 21, 1-14.

Lafuente R, Paneque P and Vargas J (2018) The role played by environmental concern and institutional trust in changing public preferences for water management. Environmental Policy and Governance 28, 441-452.

Oh H and Hong JH (2012) Citizens' trust in government and their willingness-to-pay. Economics Letters 115, 3345-347.

Scartascini C and Tommasi M (2010) The politics of productivity. In Pages C (eds.). The Age of Productivity: Transforming Economies from the Bottom Up. Palgrave Macmillan.

Scartascini C and Tommasi M (2014) Government capabilities in Latin America: why they are so important, what we know about them, and what to do next. Policy brief, Inter-American Development Bank. Available at https://www.iadb.org/en/research-and-data/publications?pub_id=IDB-PB-210.

Scartascini C and Valle Luna J (2020a) The elusive quest for growth in Latin American and the Caribbean: the role of trust. Technical report, Inter-American Development Bank. 
Scartascini C and Valle Luna J (2020b) How much do we trust others in LAC? The role of inequality and perceptions. Technical report, Inter-American Development Bank.

Sun C, Yuan X and Xu M (2016) The public perceptions and willingness-to-pay: from the perspective of the smog crisis in China. Journal of Cleaner Production 112, 1635-1644.

Volland B (2017) The role of risk and trust attitudes in explaining residential energy demand: evidence from the United Kingdom. Ecological Economics 132, 14-30.

World Bank and Institute for Health Metrics and Evaluation (2016). The Cost of Air Pollution: Strengthening the Economic Case for Action. The World Bank, Washington, DC: World Bank.

Xu J and Li J (2016) Tax payment, social contribution for pollution prevention and happiness. Problemy Ekorozwoju-Problems of Sustainable Development 11, 59-64.

Zannakis M, Wallin A and Johansson LO (2015) Political trust and perceptions of the quality of institutional arrangements-how do they influence the public's acceptance of environmental rules. Environmental Policy and Governance 25, 424-438.

Zhong Y and Hwang W (2016) Pollution, institutions and street protests in urban China. Journal of Contemporary China 25, 216-232.

Cite this article: Hoffmann BL, Scartascini C, Cafferata FG (2022). How can we improve air pollution? Try increasing trust first. Environment and Development Economics 27, 393-413. https://doi.org/10.1017/ S1355770X2100036X 